\title{
Grass intake and grazing behaviour of dry and suckling ewes according to sward height
}

\author{
M Petit, G Béchet
}

\author{
INRA, Adaptation des Herbivores aux milieux, Theix, 63122 St-Genès-Champanelle, France
}

Intake of grass depends both on animal status (physiological state, body reserves) and on sward characteristics. Grass availability and more especially its height has a major effect on intake (Hodgson, 1985, Proc Nutr Soc, 44, 339346 ). The aim of the present study was to measure the interactions between ewes' status (lactating vs dry) and sward height on the intake of grass and its behavioural components. A group of 12 Limousine $x$ Romanov 3-6 year old ewes, six of them dry and the other six suckling twins for 6 weeks, were strip-grazed on short (4-6 days old) leafy cocksfoot regrowths. Another similar group at the same time grazed longer ( 3 weeks old) and mainly leafy regrowths. The short sward was grazed from 10 down to $6 \mathrm{~cm}$ high measured with a sward stick, and the tall one from 20-25 down to $12-15 \mathrm{~cm}$. Grass intake (IG) was estimated individually by the alkanes' technique (Mayes et al, 1986, J Agric Sci, 107, 161-170). The external marker (C32) was given for 12 successive days ; faeces and hand plucked grass samples were obtained each morning during the last 9 days. Daily grazing time (GT; head down) was recorded on one day every 10 min from before the ewes stood up at dawn to after all ewes stopped grazing at dusk (15 hours), and biting rate (BR) was recorded for two minutes on 8-17 separate occasions then divided by corresponding grazing time. Bite weight was estimated by dividing IG by GT $x$ BR. Suckling ewes had far higher IG than dry ones $(P<0.001)$. They intake also more grass on tall than on short sward $(P<0.05)$, unlike the dry ewes (table). There was also a tendency for the heavier $(P=0.1)$ and the thinner

\begin{tabular}{|c|c|c|}
\hline \multirow{2}{*}{$\begin{array}{l}\text { Status of ewes } \\
\text { Sward height }\end{array}$} & \multicolumn{2}{|c|}{ suckling twins (s) } \\
\hline & tall & short \\
\hline Grass intake $(g / d)$ & 2391 & 1863 \\
\hline Grazing time $(\mathrm{min} / \mathrm{d})$ & 362 & 418 \\
\hline Biting rate $(/ \mathrm{min})$ & 40.9 & 67.7 \\
\hline Bites $\left(10^{3} / \mathrm{d}\right)$ & 14.8 & 28.3 \\
\hline Bite weihgt (mg) & 162 & 66 \\
\hline Ewes LW gain (kg/d) & 0.22 & 0.12 \\
\hline Litter gain $(\mathrm{g} / \mathrm{d})$ & 587 & 507 \\
\hline
\end{tabular}

$(P=0.2)$ ewes to eat more grass.

All ewes grazed the short sward for a longer time $(P<0.01)$ than the tall sward, with a far higher BR $(P<0.001)$, as was expected (Arnold and Dudzinski, 1978, Ethology of Free-ranging Domestic Animals, Elsevier, Amsterdam ; Penning et al, 1991, Grass For Sci, 46, 15-28). The suckling ewes grazed longer $(P<0.001)$ than the dry ones, as was already observed (Arnold, 1987, J Appl Ecol, 24, 759-772), with however a slightly higher BR $(P<0.001)$. Interactions between ewes status and sward height were not significant. Average bite weight was far greater on tall than on short sward in both type of ewes $(P<0.001)$. Suckling ewes made bigger bites than dry ewes on tall grass $(P<0.01)$, as observed previously (Parsons et al, 1994, J Anim Ecol, 63, 465-478), the difference however being small and not significant on short grass.

IG was linearly related $(P<0.01)$ within sward height to GT or number of bites per day, the relationships being the same for dry and suckling ewes.

In conclusion, the increase in IG from dry to suckling ewes results from longer GT and higher intake rate, the latter as a consequence of faster BR but also rather of heavier bite weigh at least on tall sward. Adaptative behaviour allowed the dry ewes to maintain grass intake on short sward, but not the suckling ones. It looks as if grazing time of suckling ewes could not increase more than observed on short grass, while their intake rate was greatly reduced by a lighter bite size incompletely compensated by the increase in biting rate.

\begin{tabular}{|c|c|c|c|}
\hline \multicolumn{2}{|c|}{ dry (d) } & \multicolumn{2}{|c|}{ effects } \\
\hline tall & short & $\mathrm{s} / \mathrm{d}$ & $\mathrm{t} / \mathrm{s}$ \\
\hline 1111 & 1187 & $* *$ & * \\
\hline 253 & 327 & 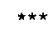 & ** \\
\hline 39.7 & 60.8 & $\star \star \star *$ & $\star \star \star *$ \\
\hline 10.0 & 19.9 & $\star * *$ & $\star \star \star *$ \\
\hline 109 & 59 & * & $\star \star \star *$ \\
\hline 0.20 & 0.24 & ns & ns \\
\hline - & - & - & $\star \star \star$ \\
\hline
\end{tabular}

